\title{
Kemo-mekanik çürük temizleme yöntemi ve geleneksel döner aletler ile temizlenen süt dişi dentin yüzeylerinin fiziko-kimyasal etkilerinin karılaştırılması
}

\section{The comparison of physico-chemical effects of chemomechanical caries removal versus conventional methods from primary teeth dentin surfaces}

\author{
Didem Özdemir Özenen, DDS, PhD, ${ }^{a}$ Gökhan Orhan, MSc, PhD, ${ }^{\mathrm{b}}$ smail Duman MSc, PhD, ${ }^{\mathrm{c}}$ Meltem \\ Karataş, DDS, PhD, ${ }^{d}$ Gürkan Özenen, MSc, ${ }^{e}$ Gamze Aren, DDS, PhD ${ }^{f}$ \\ ${ }^{a}$ Yeditepe Üniversitesi, Dişhekimliği Fakültesi, Pedodonti Anabilim Dalı, stanbul, Türkiye. \\ ${ }^{\mathrm{b}}$ stanbul Üniversitesi, Metalurji ve Malzeme Mühendisliği Bölümü, stanbul, Türkiye. \\ ${ }^{c}$ stanbul Teknik Üniversitesi, Kimya-Metalurji Fakültesi, Metalurji ve Malzeme Mühendisliği Bölümü, Üretim \\ Metalurjisi Anabilim Dalı, stanbul, Türkiye. \\ d stanbul Üniversitesi, Dişhekimliği Fakültesi, Çene-Yüz Protezi Bilim Dalı, stanbul, Türkiye. \\ ${ }^{\text {e }}$ stanbul Teknik Üniversitesi, Fen Bilimleri Enstitüsü, Bilişim Anabilim Dalı, stanbul, Türkiye. \\ ${ }^{\mathrm{f}}$ stanbul Üniversitesi, Dişhekimliği Fakültesi, Pedodonti Anabilim Dalı, stanbul, Türkiye.
}

\section{ÖZET}

Amaç: Bu çalışma, süt dişi dentini yüzeyindeki çürüğün kemo-mekanik olarak Carisolv ${ }^{\mathrm{TM}}$ multimix jeli ve geleneksel döner aletler ile temizlenmesi sonrası fiziko-kimyasal etkilerini karşılaştırmak amacıyla yapıldı.

Gereç ve Yöntem: Carisolv ${ }^{\mathrm{TM}}$ jeli ve döner aletlerle temizlenen dentin yüzey özellikleri taramalı elektron mikroskobuyla, pürüzlülükler ise yüzey profilometresi ile değerlendirildi. Bu amaçla, okluzal çürüklü çekilmiş 30 adet süt azı dişi dikey eksenine paralel olarak ikiye bölündü ve tek tarafındaki çürük lezyonu Carisolv ${ }^{\mathrm{TM}}$ jeli, diğeri ise geleneksel döner aletler ile temizlendi.

Bulgular: Carisolv ${ }^{\mathrm{TM}}$ jeli ile temizlenen dentin yüzeylerinde, döner aletlere göre pürüzlülük değerlerinde azalma olduğu fakat bu azalmanın anlamlı olmadığı saptand. Döner aletlerle temizlendikten sonra alınan SEM görüntüsünde, dentin yüzeylerindeki kollajen liflerin yer yer devamlılıklarını yitirdiği, smear tabakası ile dentin tübüllerinin tıkandığı ve uniform, düz bir yüzeyin oluştuğu gözlendi. Carisolv ${ }^{\mathrm{TM}}$ jeli ile temizledikten sonra SEM görüntüsünde dentin yüzeylerinde kollajen yapının devamlılığını sürdürdüğü, dentin tübüllerinde bir tıkanma olmadığ 1 ve döner aletlerle temizlenen dentine göre yüzeyin daha pürüzlü ve poröz bir yapıda olduğu gözlendi.

Sonuç: Bu sonuçlar 1şı̆̆ında Carisolv ${ }^{\mathrm{TM}}$ jeli ile çürük temizlemenin ardından yapılacak olan rezin bazlı restorasyonun tutuculuğunun, geleneksel döner aletlere göre daha iyi olacağı ileri sürülmektedir.

\section{ABSTRACT}

Objectives: To determine the psychomechanical properties of primary teeth dentin surfaces after caries removal with Carisolv ${ }^{\mathrm{TM}}$ multimix gel versus conventional drilling methods.

Materials and Methods: The dentin surface properties after using Carisolv $^{\mathrm{TM}}$ gel and conventional drilling were determined with scanning electron microscope and surface roughness were determined using surface profilometer. Thirty extracted primary molars were sectioned parallel to their vertical axes and Carisolv $^{\mathrm{TM}}$ gel was used to remove caries at one side, the other side were cleaned using conventional drilling methods.

Results: A decrease at the surface roughness values were observed at the samples which Carisolv $^{\mathrm{TM}}$ gel was used but this result was not significant. One part that involves occlusal dentinal caries was evaluated. The SEM results of the samples which conventional drill were used revealed no progression of the collagen fibers at the dentinal surfaces and the smear like debris layer were all over the dentinal tubulles so that a uniform and smooth layer were formed. The SEM results of the samples which conventional drill were used revealed that collagen fibrilles showed continuity, no debris layer, more surface roughness and porous layer were formed when comparing with the samples which were treated with Carisolv ${ }^{\mathrm{TM}}$.

Conclusion: It can be concluded that, the adhesion of the resin based restoration for the teeth treated with Carisolv ${ }^{\mathrm{TM}}$ gel would be preferable than the teeth treated with drills. 
Anahtar Kelimeler: Carisolv, kemo-mekanik çürük temizleme, yüzey pürüzlülüğü.

Didem ÖZDEM R ÖZENEN

Yeditepe Üniversitesi,

Dişhekimliği Fakültesi,

Pedodonti AD

Bağdat Cd. No:238

Göztepe, stanbul

Tel: +902163636044

Fax: +902163636211

E-mail: didem.ozdemir@yeditepe.edu.tr

\section{G R Ş}

Çürük dentinin kemomekanik olarak uzaklaştırılması, yumuşamış çürük dentinin ağrısız bir şeklide sağlıklı dentinden ayrılması işlemi olarak tanımlanmaktadır. Bu işlem ilk olarak, 1975 yılında Amerika'nın New Jersey eyaletinden Goldman ve Kronman isimli araştırmacılar tarafından sodyum hipoklorit kullanarak yapılmıştır. Daha sonraları, sodyum hipokloritin tek başına sağlıklı dentine çok zarar verdiği saptanmış olup, Sorensen yağ 1 denilen ve glisin, sodyum klorit ve sodyum hipoklorit içeren bir solüsyon kullanılmıştır. GK-101 veya Nmonokloroglisin (NMG) ismi verilen bu solüsyon ilk olarak 1972 yılında kullanılmıştır. $^{1-6} \quad \mathrm{~N}$-monokloroglisin (NMG) solüsyonu içerisindeki glisinin, DL-2-aminobütirik asit ile yer değiştirmesi ve böylece aktif komponentin Nmonokloro-DL-2 aminobütirik asit (NMAB) olması sonucu yeni bir solüsyon elde edilmiştir. ${ }^{7,8}$ Bileşiminde 0,10M'lık N-monokloro-DL-2 aminobütirik asit, $\% 1$ 'lik sodyum hipoklorit, 0,10M'luk $\mathrm{NaOH}$ ve $0,10 \mathrm{M}$ 'luk $\mathrm{NaCl}$ bulunan GK101E solüsyonu, 1984 yılında Birleşmiş Milletler Sağlık Örğütü'nce kullanım uygunluğuna kabul edildikten 1 y1l sonra Caridex $^{\mathrm{TM}}$ (National Patent Medical Products Inc, USA) ticari ismi altında patent alarak piyasaya sunulmuştur. Caridex ${ }^{\mathrm{TM}}$ materyalinin, çalışma süresinin uzun olması ve uygun olmayan el aletleri
Keywords: Carisolv, chemo-mechanical caries removal, surface roughness.

ile kullanımının, klinik başarıyı düşürdüğü belirtilmiştir. ${ }^{9}$

Kemomekanik olarak çürüğün uzaklaştırılması amacıyla yeni materyallerin üretimi için çalışılmış ve 1989 yılında MediTeam firması tarafından (Göteborg, sveç) geliştirilmiş olan Carisolv $^{\mathrm{TM}}$ jeli piyasaya sürülmüştür. $\mathrm{Bu}$ materyal, jel formunda olup, yine ayn firma tarafından özel üretilmiş el aletleri ile çürük dentini uzaklaştırmak amacıyla kullanılmaktadır. $\mathrm{Bu}$ jelde, Caridex ${ }^{\mathrm{TM}}$ içerisinde bulunan monoaminobütirik asit yerine etkinliğini artırmak amaciyla glutamik asit, lizin ve lösin amino asitlerinin eklendiği belirtilmiştir. Fazla miktarda solüsyonun harcanmasinı önlemek, diş yüzeyi ile daha iyi değim alanı sağlayabilmek ve kayganlığı artırmak amacı ile içerisine metil selüloz ilave edilmiştir. $^{10-1^{3}}$

Carisolv $^{\mathrm{TM}}$ jelinin alkalen $\mathrm{pH}^{\prime}$ ya sahip olduğu, böylelikle kollajen tabakasının proteolitik degradasyonunu demineralizasyondan daha iyi sağlayarak, yumuşamış çürük dentini çözdügüü, fakat sağlam dentine zarar vermediği ileri sürülmüştür. Caridex ${ }^{\mathrm{TM}}$ sisteminden farklı olarak, Carisolv ${ }^{\mathrm{TM}}$ jeli kullanımında, klinikte kullanılan el aletlerinin kullanılmadı $\breve{g}_{1}$ belirtilmiştir. Carisolv ${ }^{\mathrm{TM}}$ jelinin çürük kavitesine uygulanması, çürügün temizlenmesi ve kalan sağlıklı dentinin kontrolünü yapabilmek amaciyla, yine aynı firma tarafından künt uçlu ve ekskavasyon yapan özel el aletleri üretilmiştir. Yapılan çalışmalarda, Carisolv $^{\mathrm{TM}}$ jeli ile çürük temizlenmesi sonrası kaviteye uygulanacak restoratif maddenin dentine adezyonunun, geleneksel yöntemlerle hazırlanan kavitelerdeki adezyondan daha iyi olduğu gösterilmiştir. Bunun nedeninin, oluşan pürüzlü yüzeyin mikromekanik retansiyon sağlayarak rezin penetrasyonunu ve adezyonunu kolaylaştırması ve smear 
tabakasının uzaklaştırılmasıyla dentin kanallarının açığa çıkması olduğu belirtilmiştir. ${ }^{15-21}$

$\mathrm{Bu}$ çalışmanın amacı ise, geleneksel döner aletler ve kemomekanik yöntemle çürük temizliği yapıldıktan sonra süt dişleri dentininde oluşan yüzey özelliklerinin belirlenmesi ve karşılaştırılmasıdır. Yapılacak restorasyonlarda tutuculuğun önemi göz önünde bulundurulduğunda, geleneksel döner aletler ve kemomekanik olarak çürük temizlendikten sonra geriye kalan sağlıklı dentin yüzeylerinin mikroskopik tekstürünün belirlenmesi ve görüntülenmesi amaçlanmaktadır.

\section{GEREÇ VE YÖNTEM}

Çalışmanın deney aşaması, stanbul Teknik Üniversitesi, Kimya-Metalurji Fakültesi, Metalurji ve Malzeme Mühendisliği Bölümü, Üretim Metalurjisi Anabilim Dalı'nda gerçekleştirildi. Hedeflenen amaca yönelik olarak, geleneksel ve kemo-mekanik çürük uzaklaştırılması yöntemlerinin, süt dişleri dentin yüzeylerindeki etkilerine bakılarak, oluşan kimyasal etki mekanizması incelendi. Bu veriler, sağlam dentinle ve her iki şekilde çürüğü uzaklaştırılmış dentin yapısından elde edilen bulgularla karşılaştırd1.

\section{Örneklerin Seçilmesi}

Çürük veya sallantı nedeniyle çekilen 30 süt azı dişi kullanıldı. Çalışma kapsamına alınan dişlerdeki çürük lezyonlarının okluzal yerleşimli ve mineyi geçip dentine ulaşmış lezyonlar olmalarına dikkat edildi. Çekimden hemen sonra serum fizyolojik solüsyonu içerisinde toplanan dişler, daha sonra laboratuvar ortamında standart firçalar kullanılarak yüzeylerindeki doku artıklarından arındırıldı. Temizleme işlemlerinden sonra dişler, pH'sı 7,2 olan 0,05M fosfat tamponlu serum fizyolojik solüsyonunda 7 günden fazla olmayacak şekilde buzdolabında saklandı.
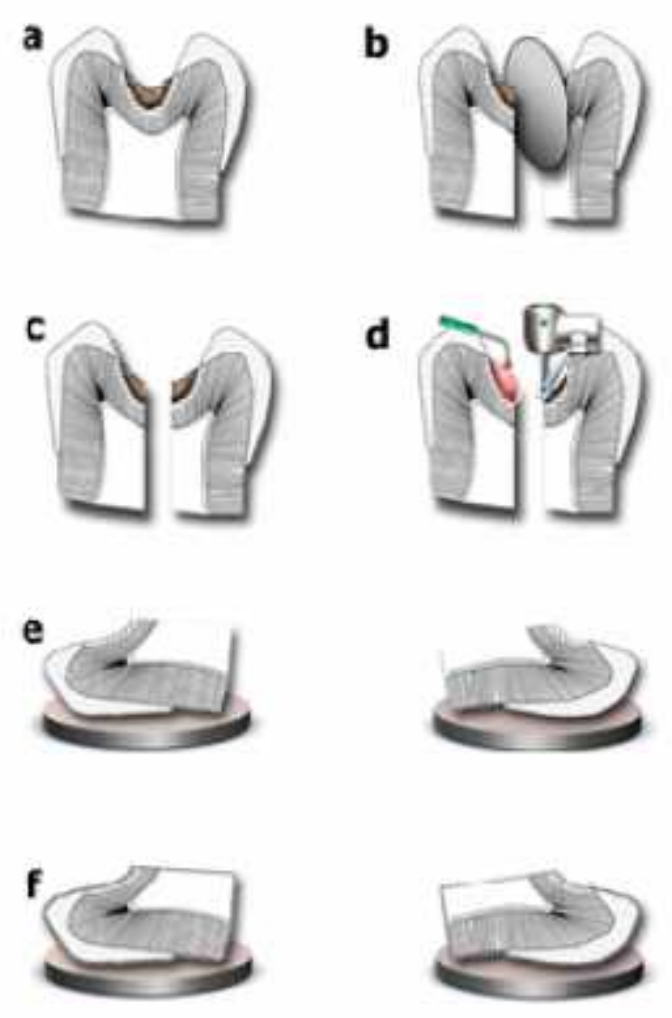

Resim 1. Yüzey incelemesi için örneklerin hazırlanması. A. Okluzal çürüklü süt dişi. B. Süt dişinin, kesici kenarından köke doğru dikey eksenine paralel kesilmesi. C. Ortadan ikiye ayrılmış süt dişindeki çürük dentin lezyonu. D. Bir tarafı Carisolv ${ }^{\mathrm{TM}}$ jeli ile diğer tarafı geleneksel döner aletlerle temizlenmiş dentin. E. Çürük lezyonu temizlendikten sonra metal levhalara oturtulmuş süt dişi. F. Metal levhalar üzerinde karbon kaplama uygulanmış süt dişi.

\section{Örneklerin Hazırlanmast}

Hepsi okluzal konumlu dentin çürüğü içeren toplam 30 adet çekilmiş süt azı dişi, kesici kenarından kök ucuna doğru dikey eksenine paralel olacak şekilde, basınçlı su soğutma sistemi ile yüksek devirde çalışan elmas diskli kesici (Isomet 1000, Buehler Company, Almanya) ile kesildi. Aynı dişteki çürük lezyonunun kesilen bir tarafına Carisolv ${ }^{\mathrm{TM}}$ multimix jeli kullanıcı firma talimatları doğrultusunda uygulanıp, 
30-60 saniye bekledikten sonra Carisolv ${ }^{\mathrm{TM}}$ jeli için özel üretilmiş el aletleri ile çürük tamamen temizlendi. Kesit alınan aynı dişin diğer bölgesindeki çürük lezyonu ise geleneksel döner aletlerle temizlendi. Her örnekte döner aletlerle kullanılan frez ve aletin devir hızının aynı olmasına dikkat edildi.

\section{Yüzey Pürüzlülü̈̆̈ünün ncelemesi}

Okluzal konumlu dentin çürügü olan 30 adet diş dikey olarak ikiye bölündükten ve aynı diş üzerindeki dentin çürük lezyonunun bir tarafı geleneksel döner aletler, diğer tarafı Carisolv ${ }^{\mathrm{TM}}$ jeli ile temizlendikten sonra, tüm örnekler düz bir zemine yerleştirildi (Resim 1A-E). Yüzey pürüzlülüğü incelemesi, Yüzey profilometresi cihazı (Perthen Mahr, Almanya) ile gerçekleştirildi. Yüzey profilometresinin değim açısı $90^{\circ}$ olacak şekilde ayarlandı. Dişin çürük dentini temizlenen yüzeyi ve okuyucu uca değecek şekilde tablonun üzerine yerleştirildi. Sabit hızla ilerleyen sürücü ünite üzerindeki dişin yüzey pürüzlülük değerleri ölçüldü ve kaydedildi.

Yüzey pürüzlülük parametreleri olarak, $\mathrm{Ra}, \mathrm{Rq}, \mathrm{Ry}$ ve $\mathrm{Rz}$ değerleri ölçüldü (Resim 2). Bu değerler;

Ra (Roughness average): Pürüzlülük düzeyi aritmetik ortalaması: Örneğin uzunluğuna göre pürüzlülük düzensizliklerinin hesaplanması ve bunların aritmetik ortalamasının alınması ile elde edildi.

$\mathrm{Rq}$ (Roughness root mean square): Örneğin uzunluğuna göre pürüzlülük düzensizliklerinin hesaplanması ve bunların geometrik ortalamasının alınması ile elde edildi.

Ry: Yüzey pürüzlülük değerlerinde ölçülen en yüksek değer (incelenen örneğin yüzeyindeki en tepe nokta) olarak kaydedildi,

Rz: Yüzey pürüzlülük değerlerinde ölçülen en yüksek beş tepe değeri ve en düşük beş çukur değerinin aritmetik ortalaması alınarak hesaplandı.

$\mathrm{Rz}=\frac{(\mathrm{R} 1+\mathrm{R} 3+\mathrm{R} 5+\mathrm{R} 7)-(\mathrm{R} 2+\mathrm{R} 4+\mathrm{R} 6+\mathrm{R} 8+\mathrm{R} 10)}{\mathrm{L}}$

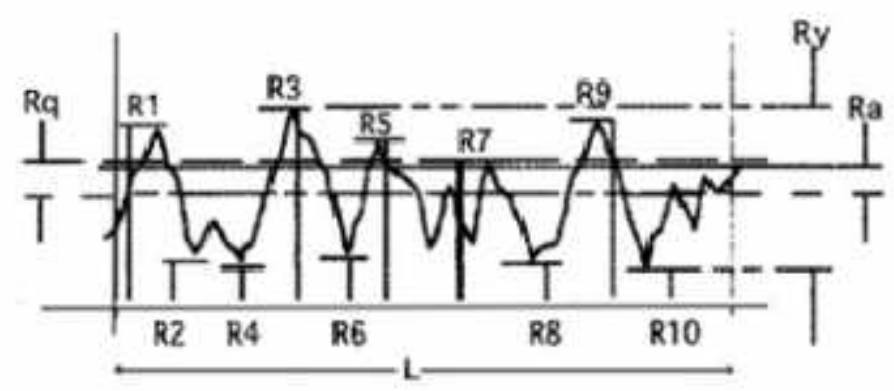

Resim 2. Yüzey profilometresinde incelenen değerlerin hesaplanmasi.

\section{Taramalı Elektron Mikroskobu ncelemesi}

Taramalı Elektron Mikroskobu (SEM) (Jeol, JSM T330) kullanılarak dentin çürügüünün uzaklaştırılmasında kullanılan iki ayrı yöntem olan geleneksel döner aletler ve kemo-mekanik temizlik amacıyla kullanılan Carisolv ${ }^{\mathrm{TM}}$ jeli ile yapılan çürük temizliği sonrası dentin yüzeyleri SEM ile incelendi. Ortadan ikiye bölünerek çürükleri iki ayrı şekilde temizlenmiş örnekler, ayrı ayrı uygun alüminyum tablolara yerleştirildi. Vakum kaplama aygıtı kullanılarak 104 torr vakum altında karbon çubuklar arasında oluşturulan arkın buharlaştırdığ 1 karbon ile tüm dişlerin yüzeyleri kaplandı. Uygun alüminyum tablolara yerleştirilerek karbon kaplama yapılan 30 adet süt azısındaki dentin çürüğ̈i temizlenen bölgeler işaretlenerek, bu bölgelerden X50'lik, X750'lik, X1500'lük ve X3500'lük büyültmelerde görüntüleri alınarak incelendi.

\section{statistiksel Analiz}

statistiksel analizler stanbul Teknik Üniversitesi, Fen Bilimleri Enstitüsü, 
Bilişim Anabilim Dalı'nda SPSS 10,0 programı kullanılarak gerçekleştirildi. Yüzey profilometresinde incelenen $\mathrm{Ra}, \mathrm{Rq}$, Ry ve $\mathrm{Rz}$ değerlerinin istatistiksel olarak incelenmesinde two-way ANOVA testi kullanıldı. $p$ değerinin 0,05 'den küçük olduğu durumlarda istatistik sonucu anlamlı kabul edildi.

\section{BULGULAR}

\section{Yüzey Pürüzlüliuk Değerleri}

Çekilmiş çürük süt dişleri uzun eksenlerine paralel olarak dikey yönde ortadan ikiye ayrdıktan sonra bir taraftaki çürük kavitesi döner aletlerle, diğer taraftaki çürük kavitesi ise Carisolv ${ }^{\mathrm{TM}}$ jeli ile temizlendikten sonra yüzey pürüzlülük değerleri yüzey profilometresinde incelendi (Resim 3). Döner aletlerle yapılan temizlik sonucunda dişlerin dentin yüzeylerinin yüzey pürüzlülük değerleri $\mathrm{Ra}, \mathrm{Rq}, \mathrm{Ry}$ ve $\mathrm{Rz}$ cinsinden hesaplandı ve yüzey pürüzlülük parametresini gösteren Ra değeri yaklaşık 7,53 $\mu$ m olarak saptandı ve diğer pürüzlülük değerleri ile birlikte kaydedildi (Tablo 1).

Aynı çürük süt dişinin Carisolv ${ }^{\mathrm{TM}}$ jeli ile temizlenen diğer yarısındaki dentin yüzeyi yüzey profilometresinde incelendiğinde (Resim 4) yüzey pürüzlülük parametresini gösteren $\mathrm{Ra}$ değeri yaklaşık $8,35 \mu \mathrm{m}$ olarak saptandı ve diğer pürüzlülük değerleri ile birlikte kaydedildi.

Döner aletlerle ve Carisolv ${ }^{\mathrm{TM}}$ jeli ile temizlenen dişlerin dentin yüzeylerinin pürüzlülük değerleri karşılaştırıldığında ise
Carisolv $^{\mathrm{TM}}$ jeli ile temizlenen dişlerin dentin yüzeylerinin, geleneksel döner aletlerle temizlenen dişlerin dentin yüzeylerine göre daha pürüzlü olduğu belirlendi (Tablo 1). Two-way ANOVA ile yapılan istatistiksel karşılaştırma sonucunda ise bu farkın istatistiksel olarak anlamlı olmadığ saptand $_{1}(p>0,5)$.

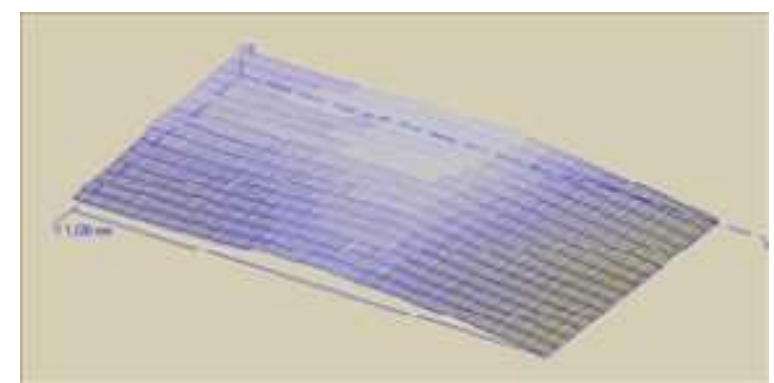

Resim 3. Geleneksel döner aletlerle temizlenmiş dentin yüzeyinin yüzey profilometresinde görüntüsü.

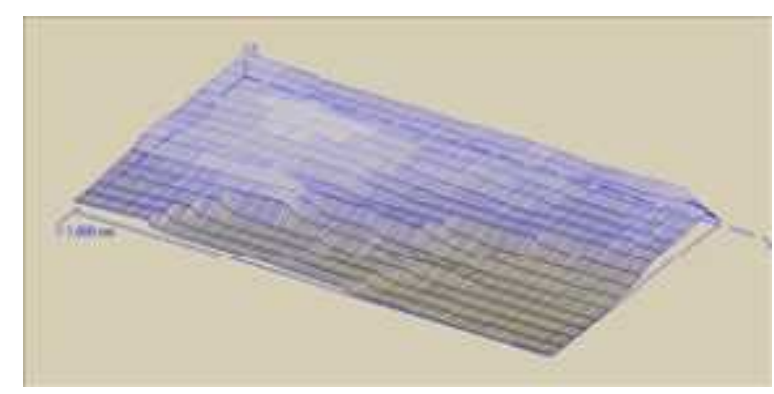

Resim 4. Carisolv ${ }^{\mathrm{TM}}$ jeli ile temizlenmiş dentin yüzeyinin yüzey profilometresinde görüntüsü.

Tablo 1. Geleneksel döner aletlerle ve Carisolv ${ }^{\mathrm{TM}}$ jeli ile temizlenen dişlerde dentin yüzey pürüzlülük değerleri ( $\mu \mathrm{m}$ cinsinden belirtildi).

\begin{tabular}{l|llll}
\hline & $\boldsymbol{R} \boldsymbol{a}$ & $\boldsymbol{R} \boldsymbol{R}$ & $\boldsymbol{R} \boldsymbol{R}$ \\
\hline Döner Aletler & $7,53 \pm 0,52$ & $8,21 \pm 0,74$ & $35,12 \pm 1,78$ & $\mathbf{2 1 , 4 3} \pm \mathbf{1 , 9 8}$ \\
\hline Carisolv $^{\mathrm{TM}}$ & $\mathbf{8 , 3 5} \pm \mathbf{0 , 3 2}$ & $\mathbf{1 0 , 4 0} \pm \mathbf{0 , 5 1}$ & $\mathbf{4 3 , 7 1} \pm \mathbf{2 , 8 1}$ & $\mathbf{2 9 , 2 5} \pm \mathbf{2 , 7 5}$ \\
\hline
\end{tabular}




\section{Taramali Elektron Mikroskobu Değgerlendirmesi}

Geleneksel döner aletlerle temizlenen dentin yüzeyi Taramalı Elektron Mikroskobu ile incelendiğinde, çürük temizliği sonrasında geriye kalan dentin yüzeyinde kollajen liflerin yer yer devamlılıklarını yitirdiği, dentin tübüllerinin tıkandığı ve smear tabakasının oluştuğu gözlendi. Ayrıca, dentinde uniform, düz bir yüzeyin oluştuğu saptandı (Resim 5A ve B).

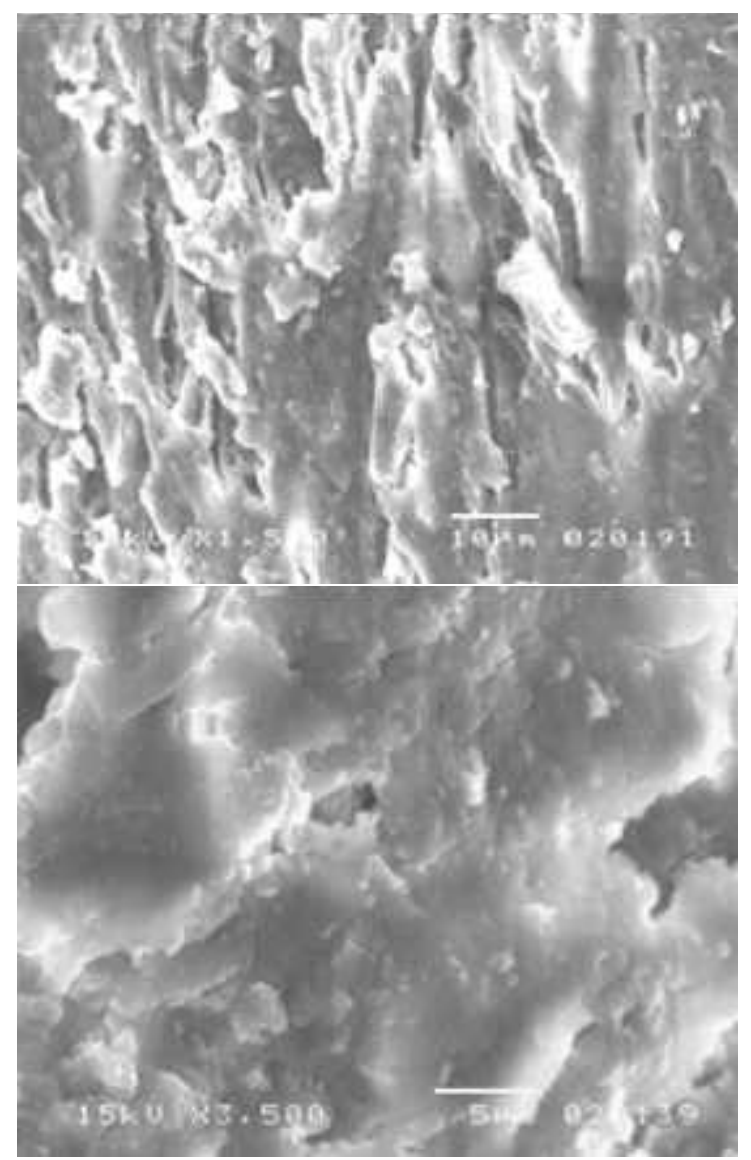

Resim 5. Döner aletlerle temizlenen dentin yüzeyinden alınan SEM görüntüsü. A. X1500, B. X3500.

Sağlıklı dentin yüzeyi ile karşılaştırıldığında, Carisolv ${ }^{\mathrm{TM}}$ jeli ile temizlenen dentin yüzeyinde, çürük temizlendikten sonra, kollajen yapının devamlılığını sürdürdüğü gözlendi. Dentin tübüllerinde bir tıkanma olmadı̆̆ı, tübül açıklıklarının X3500'lik büyültmede gözlenebildiğini ve döner aletlerle temizlenen dentine göre yüzeyin daha pürüzlü ve poröz bir yapıda olduğu saptand 1 (Resim 6A ve B).

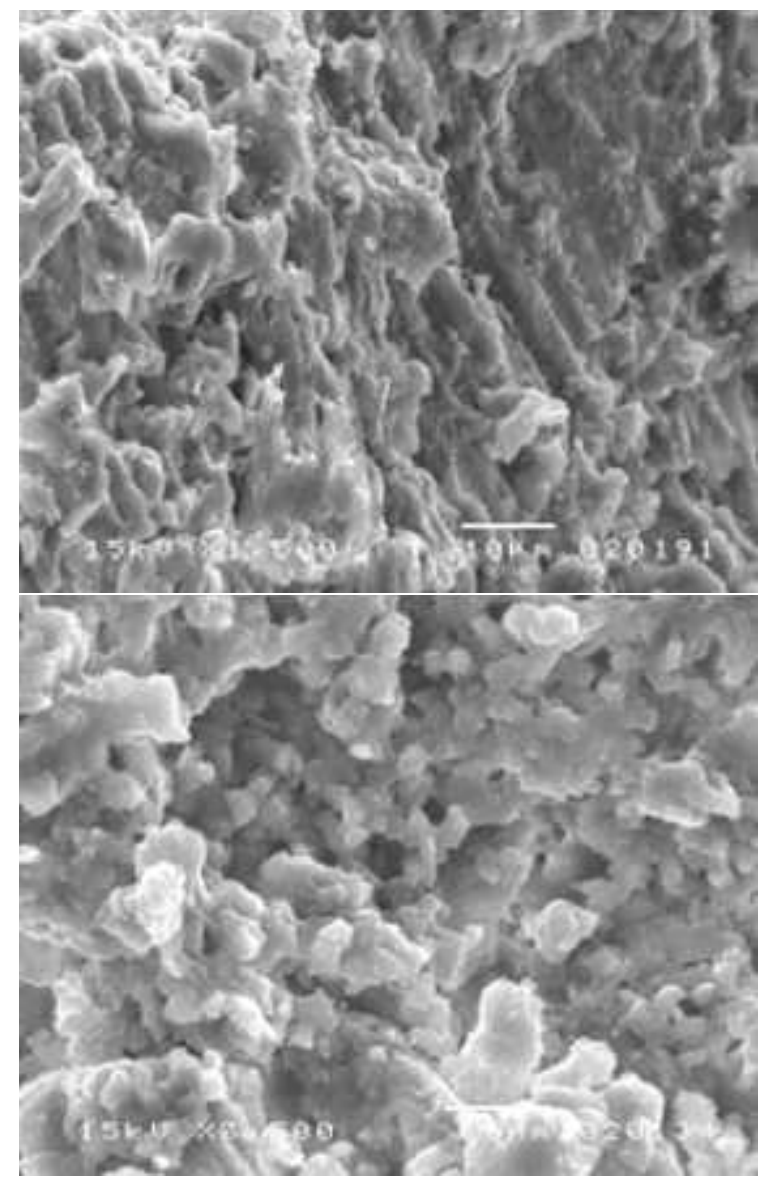

Resim 6. Carisolv ${ }^{\mathrm{TM}}$ jeli ile temizlenen dentin yüzeyinden alınan SEM görüntüsü. A. X1500, B. X3500.

\section{TARTIŞMA}

Çürük dentinin uzaklaştırılması amacıyla günümüzde birçok yöntem olduğu bilinmektedir. Bu yöntemler gerek mekanik gerek kemo-mekanik işlemleri içermekte olup temizlenen dentin yüzeylerinde oluşturdukları farklar açısından incelenmeleri amacıyla yapılan pek çok sayıda araştırma bulunmaktadır. Banerjee ve ark., ${ }^{22}$ sürekli dişlerdeki çürük lezyonları; el aletleri, döner aletler, air- 
abrazyon, sono-abrazyon ve Carisolv ${ }^{\mathrm{TM}}$ jeli ile temizleyerek, dentin yüzeylerini taramalı elektron mikroskobu (SEM) ile inceledikleri çalışmalarında, el aletleri ile çürügün temizlenmesi sonucunda fazla miktarda dentin tübülünün açığa çıktığı ve yüzeyde smear tabakası oluştuğunu gözlemişlerdir. Araştırmacılar, döner aletlerle yapılan temizleme işlemi sonucunda yüzeyde bir smear tabakası oluştuğunu ve yüzeyin oldukça pürüzlü olduğunu saptamışlarıdır. Carisolv ${ }^{\mathrm{TM}}$ jeli ile yapilan temizleme sonucunda ise, dentin yüzeyinde ince, pürüzlü bir tabaka oluştuğunu belirtmişlerdir. $\mathrm{Bu}$ çalışmada ise çürük süt dişleri kullanıldı ve Carisolv $^{\mathrm{TM}}$ jeli ile yapılan çürük temizliği sonrasinda dentin tübüllerinin smear benzeri bir debris tabakası ile tıkandığ gözlenmiş olup, Banerjee ve ark. sürekli dişlerde yapıkları çalışma sonuçlarıyla farklılık göstermektedir.

Sakoolnamarka ve ark., ${ }^{23}$ sürekli dişlerde dentin çürüğünün kemo-mekanik olarak ve geleneksel döner aletlerle yöntemlerle temizlenerek çeşitli asit uygulamaları sonrası yüzey özelliklerini taramalı elektron mikroskobu (SEM) ile incelemişlerdir. Araştırmacılar, geleneksel döner aletle temizlerek fosforik asit uygulanan örneklerde, örneklerin intertübüler dentinlerinde mikroporozitenin belirginleştiğini, poliakrilik asit uygulanan örneklerde ise artık smear tabakasının kaldığını saptamışlardır. Carisolv ${ }^{\mathrm{TM}}$ jeli uygulanan örneklerde, peritübüler ve intertübüler dentin kollajen ağının gözlendiğini, fosforik asit uygulanan örneklerde ise demineralizasyon derinliğinin çok farklı olmadığını belirtmişlerdir. Bu çalışmada ise süt dişleri kullanılmış olup kemo-mekanik olarak çürük temizlenmesi sonrası taramalı elektron mikroskobu görüntüleri Sakoolnamarka ve ark. çalışmasındaki görüntüler ile benzerlik gösterdiği saptandı. Bu çalışmada ayrıca, süt dişi dentin yüzeylerindeki çürük döner aletlerle temizlenen dişlerde, dentin tübüllerinin yer yer smear tabakası ile tıkandığ 1 gözlenirken, Carisolv ${ }^{\mathrm{TM}}$ jeli ile temizlenen dentin örneklerinde dentin tübüllerinde herhangi bir smear tabakası olmadı ğ saptand.

Carisolv $^{\mathrm{TM}}$ jeli ile temizlenen dentin yüzeylerinde, döner aletlerle yapılan çürük temizliği ile karşılaştırılması elektron mikroskobunda yapıldığında, daha poröz bir yap1 oluştuğu gözlenmesi, asitle dağlama sonucu oluşan porözite ile farklılık olup olmadığı sorusunu gündeme getirmiştir. $\mathrm{Bu}$ konuda yapılmış çok araştırma bulunmamakla birlikte, Hannig, ${ }^{24}$ Carisolv $^{\mathrm{TM}}$ jeli, fosforik asit ve fosfat tamponlu laktik asit solüsyonlarının etkilerini karşılaştırarak Carisolv ${ }^{\mathrm{TM}}$ 'un sağlıklı, demineralize ve denatüre dentin yüzeylerindeki mikromorfolojik etkileri incelemiştir. Transmisyon elektron mikroskobunda (TEM) incelediği örneklerde, Carisolv ${ }^{\mathrm{TM}}$ uygulanan dişlerde, normal dentin yüzeylerinden farklı özellikler gözlemediğini, fosforik asit uygulanan dişlerde ise demineralizasyon oluştuğunu belirtmiştir. Araştırmacı, Carisolv ${ }^{\mathrm{TM}}$ jeli uygulamasi sonucunda, demineralize dentin yüzey tabakasında yapısal çözünme oluşmadığını ve bu nedenle, Carisolv ${ }^{\mathrm{TM}}$ jeli ile yapilan temizlemenin, dentindeki bozulmamış kollajen matriksi koruduğunu ileri sürmüştür. $\mathrm{Bu}$ çalışmada ise, Carisolv ${ }^{\mathrm{TM}}$ jeli ile temizlenen dentin yüzeyleri SEM ile incelendiğinde poröz bir yapının oluştuğu, fakat döner aletlerle yapılan çürük temizliği sonrasında dentin yüzeylerinde porözitenin gözlenmediği, daha düz bir yapının oluştuğu saptandı.

Kemo-mekanik çürük temizliği sonrası gözenekli bir yapıya sahip olan dentinin yüzey pürüzlülük değerlerinde önemli değişikliklere neden olmadığını gösteren çalışmalar yapılmıştır. Silverstone ve ark., ${ }^{25}$ fosforik asit sonrası sağlıklı ve çürük başlangıcı olan mine yüzeylerini SEM ile inceledikleri çalışmalarında çürük 
başlangıcı olan mine yüzeylerinin daha gözenekli olduğunu ve mine interprizmatik boşluklarının arttığını saptamışlardır. Histopatolojik ve topografik etkilerde ise anlamlı farklar saptamadıklarını bildirmişlerdir. $\mathrm{Bu}$ çalışmada, süt dişlerinde dentin çürükleri bulunan dişler incelendiği için, Carisolv ${ }^{\mathrm{TM}}$ jelinin süt dişi minesine etkileri değerlendirilmedi.

Döner aletlerle temizlenen dentin yüzeylerinin uniform bir yapıya, Carisolv $^{\mathrm{TM}}$ jeli ile temizlenen dentin örneklerinin ise daha poröz ve çukurcuklu bir yapıya sahip olması, dentin yüzey morfolojisinde topografik incelemelerin yapılmasına neden olmuştur. Arvidsson ve ark. $^{26}$ Carisolv ${ }^{\mathrm{TM}}$ jeli uygulaması sonucunda dentin yüzeylerinin kimyasal ve topografik olarak analiz ettikleri çalışmalarında, sürekli dişlerdeki dentin çürüğünün, Carisolv ${ }^{\mathrm{TM}}$ jeli ve döner aletlerler ile temizleyerek incelemişlerdir. Yaptıkları topografik analizlerde, Carisolv $^{\mathrm{TM}}$ jeli ile temizlenen çürük dişlerin dentin yüzeylerinin döner aletlerle yapılan temizliğe göre daha pürüzlü bir yüzey oluşturduğunu belirlemişler, fakat aradaki farkın anlamlı olmadığını ileri sürmüşlerdir ${ }^{1}$. Bu çalışmada yüzey morfolojisinin incelenmesi amaciyla yüzey profilometresi kullanıldı. Çürük dentinin yarısı döner aletlerle, diğer yarısı Carisolv $^{\mathrm{TM}}$ jeli ile temizlenen süt dişinde Carisolv $^{\mathrm{TM}}$ jeli temizliği sonrasında yüzey pürüzlülüğgüün arttı̆̆ fakat döner aletlerle karşılaştırıldı ̆̆ında bu artışın istatistiksel olarak anlamlı olmadığı saptandı.

\section{SONUÇ}

Yapılmış çalışmalar 1şı̆̆ında, kemomekanik olarak çürük temizlenmesi amaciyla kullanılan Carisolv ${ }^{\mathrm{TM}}$ jelinin sürekli diş dentini üzerinde olumsuz etki oluşturmadığı, ileri sürülebileceği gibi, geleneksel döner aletler ile karşılaştırıldı ğında ise sonuçların anlamlı farklar oluşturmadığı görülmektedir. Bu çalışmanın sonuçlarına göre, süt dişlerinde bulunan dentin çürüğü lezyonlarının temizlenmesinde, kemo-mekanik temizleme ajanı Carisolv ${ }^{\mathrm{TM}}$ jeli ve geleneksel döner aletlerin kullanımı karşılaştırılmış olup bu jelin kullanımının süt dişleri dentininde istatistiksel olarak anlamlı derecede yüzey pürüzlülüğü oluşturmadığı saptanmıştır. Fakat geleneksel döner aletler ile süt dişlerindeki dentin çürüğ̈̈ temizlendikten sonra, dentin yüzeylerinde fazla miktarda madde kaybı ve dolayısıyla kollajen liflerin yapısında yer yer bozulmalar meydana geldiği görülmüştür. $\mathrm{Bu}$ sonuç ise süt dişlerinde geleneksel döner aletler ile temizlenen dentinin yapısında oluşan değişikliklerin, geri dönüşümsüz farklılıklar meydana getirebileceğini gösterir niteliktedir. Kemo-mekanik olarak dentin çürügüüün temizlenmesi amaciyla kullanılan Carisolv $^{\mathrm{TM}}$ jelinin ise sadece okluzal yüzeyli çürüklerde ve kole çürüklerinde kullanımının endike olduğu düşünüldüğünde ise bu amaçla kullanılacak daha etkili ürünlerin üretilmesi sorunu gündeme gelmektedir.

Sonuç olarak, süt dişleri dentininde oluşan çürükler değerlendirildiğinde, özellikle süt azılarında sıklıkla arayüz çürüklerinin oluşması, kemo-mekanik olarak çürük dentin dokusunun uzaklaştırılması amacıyla kullanılan bu jelin kullanım alanını kısıtlar tarzda olduğu ileri sürülebilmektedir.

\section{KAYNAKLAR}

1. Brannstrom M, Johnson G, Friskopp J. Microscopic observations of the dentin under caries lesions excavated with the GK-101 technique. ASDC J Dent Child 1980;47(1):46-49.

2. Habib CM, Kronman J, Goldman M, (eds). Mechanisms of GK 101 activity of collagen and hydroxyproline. J Dent Res 1974;53:147.

3. Habib CM, Kronman M. A chemical evaluation of collagen and 
hydroxyproline after treatment with GK-101 (N-Chloroglycine). Pharm Ther Dent 1975;2:209-215.

4. Kronman J, Goldman M, Cataldo M. Study of the effects of GK-101 (Nmonochloroglycine) on the dental pulp. J Dent Res 1976;55(6):1135.

5. Schutzbank SG, Galaini J, Kronman JH, Goldman M, Clark RE. A comparative in vitro study of GK101 and GK-101E in caries removal. J Dent Res 1978;57(9):861-864.

6. Schutzbank SG, Marchwinski M, Kronman JG, Goldman M, Clark RE. In vitro study of the effect of GK101 on the removal of carious material. J Dent Res 1975;54(4):907.

7. Tonami K, Araki K, Mataki S, Kurosaki N. Effects of chloramines and sodium hypochlorite on carious dentin. J Med Dent Sci 2003;50(2):139-146.

8. Yip HK, Stevenson AG, Beeley JA. An improved reagent for chemomechanical caries removal in permanent and deciduous teeth: an in vitro study. J Dent 1995;23(4):197204.

9. Wedenberg C, Bornstein R. Pulpal reactions in rat incisors to Caridex. Aust Dent J 1990;35(6):505-508.

10. Chaussain-Miller C, Decup F, Domejean-Orliaguet S, Gillet D, Guigand M, Kaleka R, Laboux O, Lafont J, Medioni E, Serfaty R, Toumelin-Chemla F, Tubiana J, Lasfargues JJ. Clinical evaluation of the Carisolv chemomechanical caries removal technique according to the site/stage concept, a revised caries classification system. Clin Oral Investig 2003;7(1):32-37.

11. Kakaboura A, Masouras C, Staikou O, Vougioklakis. A comparative clinical study on the Carisolv caries removal method. Quintessence Int. 2003;34(4):269-271.
12. Kubo S, Li H, Burrow MF, Tyas MJ. Nanoleakage of dentin adhesive systems bonded to Carisolv-treated dentin. Oper Dent 2002;27(4):38795.

13. Petruzillo MA, McNierney HD. Chemomechanical caries removal system in pediatric dentistry. N Y State Dent J 1988;54(2):29-32.

14. Zinck JH, McInnes-Ledoux $P$, Capdeboscq C, Weinberg R. Chemomechanical caries removal- a clinical evaluation. J Oral Rehabil 1988;15(1):23-33.

15. Burrow MF, Bokas J, Tanumiharja M, Tyas MJ. Microtensile bond strengths to caries-affected dentine treated with Carisolv. Aust Dent J 2003;48(2): 110-114.

16. Cederlund A, Lindskog S, Blomlöf J. Efficacy of Carisolv-assisted caries excavation. Int $\mathbf{J}$ Periodontics Restorative Dent 1999;19(5):465469.

17. Cehreli ZC, Yazici AR, Akca T, Ozgunaltay G. A morphological and micro-tensile bond strength evaluation of a single-bottle adhesive to caries-affected human dentine after four different caries removal techniques. J Dent 2003;31(6):429435.

18. Haak R, Wicht MJ, Noack MJ. Does chemomechanical caries removal affect dentine adhesion? Eur J Oral Sci 2000;108:449-455.

19. Harada N, Sonoda $H$, Shimada $Y$, Inai N, Otsuki M, Tagami J. Effect of chemo- mechanical caries removal on dentin bonding. J Dent Res 2000;79:372.

20. Hosoya Y, Kawashita Y, Marshall GW Jr, Goto G. Influence of CarisolvTM for resin adhesion to sound human primary dentin and young permanent dentin. J Dent 2001;29(3):163-171. 
21. Hossain M, Nakamura $Y$, Tamaki $Y$, Yamada Y, Jayawardena JA, Matsumoto K. Dentinal composition and Knoop hardness measurements of cavity floor following carious dentin removal with Carisolv. Oper Dent 2003;28(4):346-351.

22. Banerjee A, Kidd EAM, Watson TF. Scanning electron microscopic observations of human dentine after mechanical caries excavation. J Dent 2000;28(3):179-186.

23. Sakoolnamarka R, Burrow MF, Kubo S, Tyas MJ. Morphological study of demineralized dentine after caries removal using two different methods. Aust Dent J 2002;47(2):116-122.
24. Hannig M. Effect of CarisolvTM solution on sound, demineralized and denatured dentin- an ultrastructural investigation. Clin Oral Investig 1999;3:155-159.

25. Silverstone LM, Hicks J, Featherstone M. Dynamic factors affecting lesion initiation and progression in human dental enamel. Quintessence Int 1988;19(10):683711.

26. Arvidsson A, Liedberg B, Moller K, Lyven B, Sellen A, Wennerberg A. Chemical and topographical analyses of dentine surfaces after Carisolv treatment. J Dent 2002;30(2):67-75. 